\title{
Cattle milk processing and marketing characteristics among agro-pastoralists in North West Nigeria
}

\author{
${ }^{1}$ Iyiola-Tunji, A. O., ${ }^{1}$ Buba, W., ${ }^{1}$ Saleh, I., ${ }^{1}$ Mohammed, A. T., ${ }^{1}$ Yusuf, M. A. and \\ ${ }^{2}$ John, P. A.

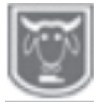 \\ Abstract

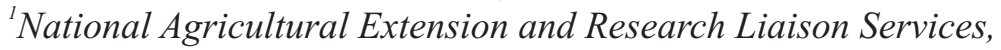 \\ Ahmadu Bello University Zaria. \\ ${ }^{2}$ Department of Animal Science, Ahmadu Bello University, Zaria \\ tunjiyiola@ynaerls.gov.ng; +2347034234136
}

The study was aimed at analysing the fundamental characteristics of milk collection, processing and marketing among agro-pastoralists in North West Nigeria. A three stage (multi-stage) sampling technique was used for the study. The first stage is the purposive selection of four States (Jigawa, Kaduna, Kano and Katsina States purposively selected based on the high concentration of agro-pastoralists). In the second stage, two Local Government Areas (LGA) from each of the State were purposively selected. The third stage involved the use of snowball sampling method for the selection of communities where agropastoralist were interviewed using structured questionnaire. Two communities were selected per LGA. Data were collected from 157 respondents from the target population out of sampled agro-pastoral households. The survey instrument was pretested and subjected to face validity. The data obtained were analysed using descriptive statistics of frequency counts and percentages. The average length of time for milk storage before processing was 1 hour and 41 minutes. Pasteurization was the method of choice used to prevent milk spoilage by 63.8\% of respondents in all the States considered in this study. Almost all (91.2\%) of the respondents market their milks. Spoilage of milk during the period before processing was reported as the highest constraint to milk production, processing and marketing in all the four States. Inadequate equipment and milk loss during processing were also reported as constraints by 18.9 and $14.7 \%$, respectively. Low quality of milk, especially during dry season, also constitute a constraint to about $4 \%$ of the respondents. The agro-pastoralists in North West Nigeria are engaged in peasantry profitable ventures of milk processing and marketing. Most of them are not members of groups and cooperatives. Their volume of trade in milk processing and marketing can be greatly enhanced if they are organized into productive groups along the value chain. Past efforts at organizing milk processors and marketers into groups and cooperatives need to be revisited by relevant agencies of government and non-government organizations.

Keywords: Agro-pastoralists, milk processing; milk marketing

\section{Introduction}

The demand for most essential food commodities are expected to move up with increasing population. This is truer when supply has tendencies to remain relatively constant. The shortage in supply gaps for such food commodities like milk most times is bridged by importation in a lethargic economy that is not capable of expanding productive value chain to meet and surpass demand. The traditional means of milk production, processing and marketing in Nigeria, as practiced by the pastoral and agro-pastoral livestock farmers, have the tendencies to contribute enormously to the supply of milk to large proportions of the demanding population for the commodity. These potentials for milk production by pastoral communities are limited by arrays of problems. Among such problems in Nigeria are low milk 


\section{Cattle milk processing and marketing characteristics}

output of indigenous cows, poor grass quality that leads to low milk yield, and inadequate storage and processing equipment (FAO, 2016).

The inefficient method of collection and distribution of milk also hinder dairy development. Most milk producing areas are in the villages, where vehicles cannot reach easily. The lack of access roads and specialized vehicles necessitate the delivery of milk by foot or by animals. Transportation by foot or on the hooves is obviously slow, and it may contribute to the dairy business failure. This is because milk is highly perishable and prone to microbial spoilage due to its high moisture and nutrient profiles (Schmidt et al., 2009). The inability of the pastoral and agro-pastoral locals to deliver the milk to the few available processing firms within the critical four hours after milking usually contribute to more than half of the milk spoilage before reaching the final consumer (Ismail, 2010). The issue surrounding dairy industry, therefore, calls for a reform in the sector. Dairy milk value chain reform would bring an opportunity to deliver change and modernization to the dairy industry and therefore unlock the very great potential of the livestock industry of Nigeria (Waters-Bayer, 1985; NLPD, 1992; FAO, 2016).

Processing of milk into dairy products such as cheese, yoghurt, butter, butterfat aside from increasing the shelf-life also increases the premium paid by consumers because of value-addition over and above the amount payable for fresh milk (Gegner, 2001). According to FAO (1988), the dairy industry provides a means of livelihood for a significant proportion of rural pastoral families in the sub-humid and semi-arid ecological zones of Nigeria. This ability of the dairy enterprise to generate regular income and to contribute to the household diet on a regular basis throughout the year is an advantage over some other agricultural enterprises (Muriuki, 2001). The snag of the business development from milk production, processing and marketing as being practiced by pastoralists and agropastoralists is the unorganized nature of the ventures (Olaloku, 1976; Yahuza, 2001 and Osotimehin, 2006).

It is however opined that intervention towards organizing milk collection, processing and marketing will be easier with the agro-pastoralists (resident Fulanis that practice mixed farming of crop and livestock production in stationary locations). This study was therefore aimed at analysing the fundamental characteristics of milk collection, processing and marketing among agro-pastoralists in North West Nigeria.

\section{Methodology}

The study was carried out in North West Nigeria. This region is made up of seven States namely: Jigawa, Kaduna, Katsina, Kano, Kebbi, Sokoto and Zamfara State. The study was conducted in Jigawa, Kaduna, Kano and Katsina States purposively selected based on the high concentration of agro-pastoralists. The North Western zone has an annual mean rainfall of between $750 \mathrm{~mm}$ to $11624 \mathrm{~mm}$ and annual mean temperature of $28^{\circ}-52^{\circ} \mathrm{C}$. The weather in most parts of the North West region of Nigeria is divided into four: late dry (January - March), early wet (April June), late wet (July-September) and early dry (October - December). A three stage (multi-stage) sampling technique involving a combination of purposeful, random and snow ball sampling was used to collect data for the target population out of sampled agro-pastoral households. The first stage is the purposive selection of four States. The four States were selected purposively with due consideration of distinct agroecological conditions, agro-pastoralists 


\section{Iyiola-Tunji, Buba, Saleh, Mohammed, Yusuf and John}

presence, future development project programming, logistics, and resource availability. In the second stage, two Local Government Areas (LGA) from each of the State were purposively selected. The selection of these LGA was based on the high population of agro-pastoralists in those areas (Table 1). The third stage involved the use of snowball sampling method for the selection of communities where agro-pastoralist were interviewed using structured questionnaire. Two communities were selected per LGA. Ten respondents (agro-pastoralists) were intended to be interviewed per community using snowball sampling method. However, less than 10 (6 respondents) were interviewed at Daka Tsale in Wudil LGA of Kano State. Also 11 respondents were interviewed at Tsiga in Bakori LGA of Katsina State. In all, a total of 157 respondents were interviewed using structured questionnaire. The survey instrument was pretested and subjected to face validity. The distribution of the communities from which agro-pastoralists were interviewed is shown in Table 1. The data obtained were analysed using descriptive statistics of frequency counts and percentages.

Table 1: State, Local Government Areas and community of agrepastoralist interviewed for the study

\begin{tabular}{|c|c|c|c|}
\hline State & LGA & Communities & Number of respondents per LGA \\
\hline \multirow[t]{2}{*}{ Jigawa } & Kiyawa & $\begin{array}{l}\text { Kiyawa, } \\
\text { Karfawa }\end{array}$ & 20 \\
\hline & Birni Kudu & $\begin{array}{l}\text { Sardauna, } \\
\text { Kwari }\end{array}$ & 20 \\
\hline \multirow[t]{2}{*}{ Kaduna } & Zaria & $\begin{array}{l}\text { Kake, } \\
\text { Detu }\end{array}$ & 20 \\
\hline & Sabon Gari & $\begin{array}{l}\text { Hauwa, } \\
\text { Tudun Fulani }\end{array}$ & 20 \\
\hline \multirow[t]{2}{*}{ Kano } & Kumbotsu & $\begin{array}{l}\text { Kareken Sani, } \\
\text { Panshekara }\end{array}$ & 20 \\
\hline & Wudil & $\begin{array}{l}\text { Kura, } \\
\text { Tsale }\end{array}$ & 16 \\
\hline \multirow[t]{3}{*}{ Katsina } & Bakori & $\begin{array}{l}\text { Bakori, } \\
\text { Tsiga }\end{array}$ & 21 \\
\hline & Jibia & $\begin{array}{l}\text { Kuza, } \\
\text { Mazanya }\end{array}$ & 20 \\
\hline & & Total & 157 \\
\hline
\end{tabular}

\section{Results and discussion}

Table 2 shows the socio-economic characteristics of milk processors and marketers in some North-West States of Nigeria. The proportion of females $(51.3 \%)$ was almost equal to that of males $(48.7 \%)$ in the study area. This is because, although some of the household heads (who were mostly males) were not directly involved in milk processing, but they however made major management decisions. Also, FAO (2011) stated that women make up an average of about $43 \%$ of the agricultural labour force and contribute substantially to the livestock management. Milking and processing as well as marketing are the major aspects of milk value chain that women are mostly engaged in (Thornton, 2001). According to Dupire (1962), milk was the Fulani's main source of subsistence, 


\section{Cattle milk processing and marketing characteristics}

and the women were responsible for processing and marketing of milk, and for obtaining grain for family consumption. However, the actual let down of milk, like herding, was usually done by men and boys. The average age of farmers in this study is 36 years old. Very large proportions of these farmers are between 15 to 45 years of age. Respondents in Kaduna States $(90 \%)$ are within this age group while $88.6 \%, 80 \%$ and $77.3 \%$ are also between 15 to 45 years old in Kano, Katsina and Jigawa States, respectively. Desalenge (2016) reported similar age between 18 to 50 years as age of farmers in milk value chain in Ethiopia. Sani (2006) also reported an average age of 40 years for milk producers, processors and marketers in Kaduna State. The findings of Osotimehin et al. (2006) also reported mean age being 46.51 years in Kogi State for similar population. These ages are within the range of active age of individuals that are neither too young nor too old for activities. This implies that decisions on activities surrounding milk processing and marketing were made by individuals within active and productive age. Majority of the respondents $(83.3 \%)$ are married with average household size of 9 persons. This shows a clear representation of the population studied, as Hausa/Fulani are known to marry early (Somda et al., 2004). The household size could be larger due to religiously permitted polygamy being practiced. More than half $(59.1 \%)$ of them had Qur'anic education only. About 20\% did not have any form of education. According to Iro (2018), in a sample of 1,998 pastoral Fulani surveyed, about half of them have Qur'anic education, forty percent have no education, and only seven percent have either formal or both mainstream and Qur'anic education. To reduce illiteracy among them, government introduced the nomadic education program which among its goals is to bridge the literacy gap between the Fulani and rest of the society. They are farmers who practice mixed farming $(53.9 \%)$. Some are engaged as nomadic cattle farmers $(10.4 \%)$ and about $30 \%$ are milk processors. The high proportion of farmers in this study that practice mixed farming agrees with comment made by Somda et al. (2004) that dairy production is to be seen as a component of the farming system, in which dairy and crop enterprises are associated and mutually beneficial. Gryseels (1988) also stated that smallholder dairy production can be improved without affecting the primary function of animals and could be attractive in mixed farming system, as it offers the opportunity to diversify operations, spread risk and provide income. They practiced mixfarming so as to feed their animals with the crop residues at the end of production year. Some even keep the residues until during dry season, so as to supplement grazing.

Milk processing characteristics are shown in Table 3. The average length of time for milk storage before processing was 1 hour and 41 minutes. In Jigawa State, 52.6\% of the respondents reported that the length of time for milk storage before processing was less than one hour. The average length of time for storage before processing in Jigawa State was estimated to be 1 hour and 37 minutes. In Kaduna and Kano State, the largest proportion of respondents indicated that they do store milk before commencement of processing for between 1 to 2 hours. The proportions were 50 and $68.8 \%$ for Kaduna and Kano State, respectively. The average length of time for milk storage for Kaduna and Kano State were 1 hour 26 minutes and 1 hour 41 minutes, respectively. About $45 \%$ of respondents from Katsina State don't store their fresh milk before processing. However, the estimated time for storage of fresh milk before processing among 
Iyiola-Tunji, Buba, Saleh, Mohammed, Yusuf and John

Table 2: Socio-economic characteristics of milk processors and marketers in some North West States of Nigeria

State

\begin{tabular}{|c|c|c|c|c|c|c|}
\hline Variable & Jigawa & Kaduna & Kano & Katsina & Overall & Average \\
\hline \multicolumn{7}{|l|}{$\underline{\operatorname{Sex}}$} \\
\hline$\overline{\text { Male }}$ & $20(52.6)$ & $19(47.5)$ & $16(44.4)$ & $20(50.0)$ & $75(48.7)$ & \\
\hline Female & $18(47.4)$ & $21(52.5)$ & $20(55.6)$ & $20(50.0)$ & $79(51.3)$ & \\
\hline $\mathrm{N}$ & 38 & 40 & 36 & 40 & 154 & \\
\hline \multicolumn{7}{|c|}{ Age of respondents } \\
\hline $15-25$ & $8(21.1)$ & $10(25.0)$ & $4(11.4)$ & $7(17.5)$ & $29(19.0)$ & 36 \\
\hline $26-35$ & $10(26.3)$ & $15(37.5)$ & $12(34.3)$ & $14(35.0)$ & $51(33.3)$ & \\
\hline $36-45$ & $11(28.9)$ & $11(27.5)$ & $15(42.9)$ & $11(27.5)$ & $48(31.3)$ & \\
\hline $46-55$ & $7(18.4)$ & $3(7.5)$ & $0(0.0)$ & $6(15.0)$ & $16(10.5)$ & \\
\hline $56-65$ & $2(5.3)$ & $1(2.5)$ & $2(5.7)$ & $2(5.0)$ & $7(4.6)$ & \\
\hline $66-75$ & $0(0.0)$ & $0(0.0)$ & $2(5.7)$ & $0(0.0)$ & $2(1.3)$ & \\
\hline $\mathrm{N}$ & 38 & 40 & 35 & 40 & 153 & \\
\hline \multicolumn{7}{|c|}{ Marital status } \\
\hline Single & $2(5.3)$ & $5(12.5)$ & $1(2.8)$ & $0(0.0)$ & $8(5.2)$ & \\
\hline Married & $32(84.2)$ & $31(77.5)$ & $28(77.8)$ & $38(95.0)$ & $129(83.3)$ & \\
\hline Widow & $2(5.3)$ & $3(7.5)$ & $3(8.3)$ & $1(2.5)$ & $9(5.8)$ & \\
\hline Divorced & $2(5.3)$ & $1(2.5)$ & $4(11.1)$ & $1(2.5)$ & $8(5.2)$ & \\
\hline $\mathrm{N}$ & 38 & 40 & 36 & 40 & 154 & \\
\hline \multicolumn{7}{|c|}{ House hold size } \\
\hline Small (2-6) & $4(10.8)$ & $26(76.5)$ & $6(17.1)$ & $10(26.3)$ & $46(31.9)$ & 9 \\
\hline $\begin{array}{l}\text { Medium (7- } \\
11)\end{array}$ & $18(48.6)$ & $6(17.6)$ & $14(40.0)$ & $16(42.1)$ & $54(37.5)$ & \\
\hline $\begin{array}{l}\text { Large (12- } \\
16)\end{array}$ & $12(32.4)$ & $2(5.9)$ & $10(28.6)$ & $10(26.3)$ & $34(23.6)$ & \\
\hline $\begin{array}{l}\text { Very large } \\
(\geq 17)\end{array}$ & $3(8.1)$ & $0(0.0)$ & $5(14.3)$ & $2(5.3)$ & $10(6.9)$ & \\
\hline $\mathrm{N}$ & 37 & 34 & 35 & 38 & 144 & \\
\hline \multicolumn{7}{|l|}{$\frac{\text { Education }}{\text { status }}$} \\
\hline $\begin{array}{l}\overline{\text { Quranic }} \\
\text { education }\end{array}$ & $17(44.7)$ & $36(90.0)$ & $13(36.1)$ & $25(62.5)$ & $91(59.1)$ & \\
\hline Primary & $3(7.9)$ & $0(0.0)$ & $0(0.0)$ & $11(27.5)$ & $14(9.1)$ & \\
\hline Secondary & $0(0.0)$ & $3(7.5)$ & $2(5.6)$ & $4(10.0)$ & $9(5.8)$ & \\
\hline Tertiary & $0(0.0)$ & $0(0.0)$ & $8(22.2)$ & $0(0.0)$ & $8(5.2)$ & \\
\hline $\begin{array}{l}\text { No any } \\
\text { form of } \\
\text { education }\end{array}$ & $18(47.4)$ & $1(2.5)$ & $13(36.1)$ & $0(0.0)$ & $32(20.8)$ & \\
\hline $\mathrm{N}$ & 38 & 40 & 36 & 40 & 154 & \\
\hline \multicolumn{7}{|l|}{ Primary } \\
\hline $\begin{array}{l}\text { Civil } \\
\text { servant }\end{array}$ & $0(0.0)$ & $0(0.0)$ & $3(8.3)$ & $4(10.0)$ & $7(4.5)$ & \\
\hline Trader & $0(0.0)$ & $0(0.0)$ & $2(5.6)$ & $0(0.0)$ & $2(1.3)$ & \\
\hline $\begin{array}{l}\text { Farmer } \\
\text { (mixed } \\
\text { farming) }\end{array}$ & $23(60.5)$ & $19(47.5)$ & $15(41.7)$ & $26(65.0)$ & $83(53.9)$ & \\
\hline Nomadic & $3(7.9)$ & $4(10.0)$ & $9(25.0)$ & $0(0.0)$ & $16(10.4)$ & \\
\hline Processor & $12(31.6)$ & $17(42.5)$ & $7(19.4)$ & $10(25.0)$ & $46(29.9)$ & \\
\hline $\mathrm{N}$ & 38 & 40 & 36 & 40 & 154 & \\
\hline
\end{tabular}




\section{Cattle milk processing and marketing characteristics}

farmers from Katsina State was 2 hours and 2 minutes.

Plastic buckets/bowls were majorly $(52.3 \%)$ used by the respondents who provided information on the equipment used for storing milk. Calabash, earthen pots, metal/aluminium pots were used by $34.2 \%, 8.7 \%$ and $4.7 \%$, respectively to store fresh milk. In specific terms as regards each of the four States, more farmers (respondents) used calabash in Jigawa State $(78.9 \%)$ and Kano State $(55.9 \%)$. Farmers from Kaduna $(92.3 \%)$ and katsina State $(73.7 \%)$ used plastic buckets majorly for storing fresh milk.

Pasteurization was the method of choice used to prevent milk spoilage by $63.8 \%$ of respondents in all the States considered in this study. Farmers from Jigawa (86.8\%), Kano $(85.3 \%)$ and Kaduna State $(84.2 \%)$ used pasteurization to prevent milk spoilage while only $2.6 \%$ of farmers from Katsina State used this method. Almost all the respondents $(90.8 \%)$ processed their fresh milk into other products. The preferred products into which fresh milk is being processed into were skimmed milk $(31.7 \%)$, yoghurt $(16.5 \%)$, cottage cheese (7.5\%), ghee $(2.0 \%)$ and whey $(1.1 \%)$. The distribution of respondents who preferred their milk in pasteurized and un-pasteurized forms was $93.8 \%$ and $62.6 \%$, respectively.

Table 3: Milk processing characteristics in some North West States of Nigeria

\begin{tabular}{|c|c|c|c|c|c|c|}
\hline \multirow[b]{2}{*}{ Variable } & \multicolumn{4}{|c|}{ State $(\%)$} & \multirow[b]{2}{*}{ Overall } & \multirow[b]{2}{*}{ Average } \\
\hline & Jigawa & Kaduna & Kano & Katsina & & \\
\hline \multicolumn{7}{|c|}{ Length of time for milk storage before processing } \\
\hline Never stored & $2(5.3)$ & $3(7.5)$ & $2(6.2)$ & $17(44.7)$ & $24(16.2)$ & $1 \mathrm{hr} 41 \mathrm{~min}$ \\
\hline Less than one hour & $20(52.6)$ & $11(27.5)$ & $6(18.8)$ & $2(5.3)$ & $39(26.4)$ & \\
\hline Between 1 to 2 hours & $8(21.1)$ & $20(50.0)$ & $22(68.8)$ & $9(23.7)$ & $59(39.9)$ & \\
\hline Between 2 to 3 hours & $0(0.0)$ & $6(15.0)$ & $0(0.0)$ & $2(5.3)$ & $8(5.4)$ & \\
\hline Between 3 to 4 hours & $7(18.4)$ & $0(0.0)$ & $1(3.1)$ & $1(2.6)$ & $9(6.1)$ & \\
\hline 5 hours and above & $1(2.6)$ & $0(0.0)$ & $1(3.1)$ & $7(18.4)$ & $9(6.1)$ & \\
\hline $\mathrm{N}$ & 38 & 40 & 32 & 38 & 148 & \\
\hline \multicolumn{7}{|c|}{ Equipment for storing milk } \\
\hline Plastic bucket & $7(18.4)$ & $36(92.3)$ & $7(20.6)$ & $28(73.7)$ & $78(52.3)$ & \\
\hline Calabash & $30(78.9)$ & $2(5.1)$ & $19(55.9)$ & $0(0.0)$ & $51(34.2)$ & \\
\hline Earthen pots & $1(2.6)$ & $0(0.0)$ & $2(5.9)$ & $10(26.3)$ & $13(8.7)$ & \\
\hline Metal/aluminum pots & $0(0.0)$ & $1(2.6)$ & $6(17.6)$ & $0(0.0)$ & $7(4.7)$ & \\
\hline $\mathrm{N}$ & 30 & 39 & 34 & 38 & 149 & \\
\hline \multicolumn{7}{|c|}{ Method used to prevent milk spoilage } \\
\hline Pasteurization & $33(86.8)$ & $32(84.2)$ & $29(85.3)$ & $1(2.6)$ & $95(63.8)$ & \\
\hline Sterilization & $4(10.5)$ & $5(13.2)$ & $3(8.8)$ & $0(0.0)$ & $12(8.1)$ & \\
\hline None & $1(2.6)$ & $1(2.6)$ & $2(5.9)$ & $38(97.4)$ & $42(28.2)$ & \\
\hline $\mathrm{N}$ & 38 & 38 & 34 & 39 & 149 & \\
\hline \multicolumn{7}{|c|}{ Do you process milk into other products? } \\
\hline Yes & $34(100)$ & $33(97.1)$ & $25(100)$ & $27(71.1)$ & $119(90.8)$ & \\
\hline No & $0(0.0)$ & $1(2.9)$ & $0(0.0)$ & $11(28.9)$ & $12(9.2)$ & \\
\hline $\mathrm{N}$ & 34 & 34 & 25 & 38 & 131 & \\
\hline \multicolumn{7}{|c|}{ Preferred products from fresh milk } \\
\hline Pasteurized milk & $36(94.7)$ & $37(92.5)$ & $26(92.9)$ & $6(100)$ & $105(93.8)$ & \\
\hline Unpasteurized milk & $27(73.0)$ & $12(30.8)$ & $18(66.7)$ & $20(100)$ & $77(62.6)$ & \\
\hline Yoghurt & $1(5.3)$ & $0(0.0)$ & $9(47.4)$ & $9(47.4)$ & $19(16.5)$ & \\
\hline Cottage cheese & $0(0.0)$ & $0(0.0)$ & $4(50.0)$ & $4(50)$ & $8(7.5)$ & \\
\hline Skimmed milk & $15(41.7)$ & $1(2.6)$ & $16(55.2)$ & $1(100)$ & $33(31.7)$ & \\
\hline Ghee & $0(0.0)$ & $1(2.6)$ & $1(3.6)$ & & $2(2.0)$ & \\
\hline Whey & $0(0.0)$ & $0(0.0)$ & $1(3.6)$ & & $1(1.1)$ & \\
\hline
\end{tabular}




\section{Iyiola-Tunji, Buba, Saleh, Mohammed, Yusuf and John}

Table 4 showed milk marketing characteristics in North-West Nigeria. Almost all (91.2\%) of the respondents market their milks. In fact, all the respondents from Jigawa and Kaduna States market their milk. A small proportion of respondents from Kano State $(6.9 \%)$ and a substantial number of respondents from Katsina State $(32.3 \%)$ did not sell their milk. When the form in which milk is being sold was considered, $68 \%$ of respondents indicated that they sold their milk raw as collected. Many farmers in Kaduna (69.2\%) however, sold their milks in processed forms. The wives of pastoralists usually process fresh milk into various traditional milk products. These include nono (sour milk), kindirmo (sour yoghurt), maishanu (local butter), cuku (Fulani cheese) and wara (Yoruba cheese). These products are usually hawked around the local area by women or are sold in specific locations, or local markets in certain towns. With advancement in milk processing companies, the fresh milk is being sold at home as the buyers are ready to follow them and collect. That is, some were no longer processing the milk into products as they sell at farm gate. The stated average prices of fresh milk per litre were $¥ 150, \$ 218$, \#220 and N226 in Kaduna, Katsina, Kano and Jigawa States, respectively. These variations could be due to location and ownership structures of some commercial milk processing companies. Pricing policy for raw milk by individual company or organization may differ". Butter milk yielded the highest income among processed products obtained from fresh milk. Top on the list of factors that influence marketability of cattle milk is thickness $(64.3 \%)$. Colour of milk $(40.3 \%)$ and flavour $(39.0 \%)$ were also stated to have influence on marketability of cattle milk. In the North-West of Nigeria, hawking of milk within communities (45.6\%) was reported to be the highest means of getting milk across to consumers. Milk can also be sold through cooperative societies, but most of the respondents were not members of any cooperative group.

Constraints of milk processing and marketing in some States of North West Nigeria are presented on Table 5. Spoilage of milk during the period before processing was reported as the highest constraint to milk production, processing and marketing in all the four States. Inadequate equipment and milk loss during processing were also reported as constraints by 18.9 and $14.7 \%$, respectively. Low quality of milk, especially during dry season, also constitute a constraint to about $4 \%$ of the respondents. Quality and quantity of the milk produce tend to decrease during dry season as reported by World Bank (1993), that daily milk off take per lactating cow average of 0.74 litres/day, which ranged from 0.36 litres in the dry season to 1.27 litres in the wet season. Hostility of the animals toward farmers during milk extraction was reported by $5.3 \%$ of the respondents. Diseases of cattle impaired productivity in terms of quality of milk as reported by $3.2 \%$ of 95 respondents.

\section{Conclusion}

The study showed that agro-pastoralists in North West Nigeria are engaged in peasantry profitable ventures of milk processing and marketing. Most of them are not members of groups and cooperatives. Their volume of trade in milk processing and marketing can be greatly enhanced if they are organized into productive groups along the value chain. Past efforts at organizing milk processors and marketers into groups and cooperatives need to be revisited by relevant agencies of government and non-government organizations. 
Cattle milk processing and marketing characteristics

Table 4: Milk marketing characteristics in some North West States of Nigeria

\begin{tabular}{|c|c|c|c|c|c|}
\hline \multirow[b]{2}{*}{ Variable } & \multicolumn{4}{|c|}{ State $(\%)$} & \multirow[b]{2}{*}{ Overall } \\
\hline & Jigawa & Kaduna & Kano & Katsina & \\
\hline \multicolumn{6}{|c|}{ Do you market milk? } \\
\hline Yes & $38(100)$ & $39(100)$ & $27(93.1)$ & $21(67.7)$ & $125(91.2)$ \\
\hline No & $0(0.0)$ & $0(0.0)$ & $2(6.9)$ & $10(32.3)$ & $12(8.8)$ \\
\hline $\mathrm{N}$ & $38(100)$ & $39(100)$ & $29(100)$ & $31(100)$ & $137(100)$ \\
\hline \multicolumn{6}{|c|}{ Form in which milk is being sold } \\
\hline Raw as collected & $28(73.7)$ & $8(20.5)$ & $26(83.9)$ & $20(100)$ & $87(68.0)$ \\
\hline Processed milk & $10(26.3)$ & $27(69.2)$ & $4(12.9)$ & $0(0.0)$ & $41(32.0)$ \\
\hline $\mathrm{N}$ & 38 & 39 & 31 & 20 & 128 \\
\hline \multicolumn{6}{|c|}{ Price of fresh milk per litre } \\
\hline $100-200$ & $17(44.7)$ & $31(100)$ & $11(36.7)$ & $7(31.8)$ & $66(54.5)$ \\
\hline $201-300$ & $15(39.5)$ & $0(0.0)$ & $17(56.7)$ & $15(68.2)$ & $47(38.8)$ \\
\hline $301-400$ & $5(13.2)$ & $0(0.0)$ & $2(6.7)$ & $0(0.0)$ & $7(5.8)$ \\
\hline $501-600$ & $1(2.6)$ & $0(0.0)$ & $0(0.0)$ & $0(0.0)$ & $1(0.8)$ \\
\hline $\mathrm{N}$ & $38(100)$ & $31(100)$ & $30(100)$ & $22(100)$ & $121(100)$ \\
\hline \multicolumn{6}{|c|}{ Product which yields more income } \\
\hline Butter milk & $17(44.7)$ & $13(33.3)$ & $13(43.3)$ & $11(39.3)$ & $54(40.0)$ \\
\hline Milk pasteurized & $15(39.5)$ & $25(64.1)$ & $11(36.7)$ & $0(0.0)$ & $51(37.8)$ \\
\hline Milk unpasteurized & $6(15.8)$ & $0(0.0)$ & $2(6.7)$ & $16(57.1)$ & $24(17.8)$ \\
\hline Cottage cheese & $0(0.0)$ & $0(0.0)$ & $2(6.7)$ & $1(3.6)$ & $3(2.2)$ \\
\hline Skimmed milk & $0(0.0)$ & $1(2.6)$ & $2(6.7)$ & $0(0.0)$ & $3(2.2)$ \\
\hline $\mathrm{N}$ & $38(100)$ & $39(100)$ & $30(100)$ & $28(100)$ & $135(100)$ \\
\hline \multicolumn{6}{|c|}{ Factor that influence marketability of cattle milk } \\
\hline Colour & $12(100)$ & $33(100)$ & $9(100)$ & $8(100)$ & $62(100)$ \\
\hline Flavour & $27(100)$ & $7(100)$ & $24(100)$ & $2(100)$ & $60(100)$ \\
\hline Thickness & $26(100)$ & $35(100)$ & $21(100)$ & $17(94.4)$ & $99(99.0)$ \\
\hline $\mathrm{N}$ & $26(100)$ & $35(100)$ & $21(100)$ & $18(100)$ & $100(100)$ \\
\hline \multicolumn{6}{|c|}{ Place where milk are being sold } \\
\hline Selling centre & $3(7.9)$ & $14(35.0)$ & $12(37.5)$ & $20(76.9)$ & $49(36.0)$ \\
\hline Nearest market & $2(5.3)$ & $9(22.5)$ & $9(28.1)$ & $5(19.2)$ & $25(18.4)$ \\
\hline $\begin{array}{l}\text { Hawking within } \\
\text { communities }\end{array}$ & $33(86.8)$ & $17(42.5)$ & $11(34.4)$ & $1(3.8)$ & $62(45.6)$ \\
\hline $\mathrm{N}$ & $38(100)$ & $40(100)$ & $32(100)$ & $26(100)$ & $136(100)$ \\
\hline \multicolumn{6}{|c|}{ Membership of milk cooperative group } \\
\hline Yes & $0(0.0)$ & $1(2.6)$ & $7(23.3)$ & $0(0.0)$ & $8(5.8)$ \\
\hline No & $38(100)$ & $38(97.4)$ & $23(76.7)$ & $30(100)$ & $129(94.2)$ \\
\hline $\mathrm{N}$ & $38(100)$ & $39(100)$ & $30(100)$ & $30(100)$ & $137(100)$ \\
\hline
\end{tabular}


Iyiola-Tunji, Buba, Saleh, Mohammed, Yusuf and John

Table 5: Constraints of processing and marketing in some States of North West Nigeria

\begin{tabular}{|c|c|c|c|c|c|}
\hline \multirow{2}{*}{ Variable } & \multicolumn{4}{|c|}{ State (\%) } & \multirow[t]{2}{*}{ Overall } \\
\hline & Jigawa & Kaduna & Kano & Katsina & \\
\hline \multicolumn{6}{|c|}{ Constraints of milk production, processing and marketing } \\
\hline Spoilage of milk & 5.6 & 50.0 & 14.8 & 10.0 & 23.2 \\
\hline Inadequate equipment & 27.8 & 0.0 & 37.0 & 15.0 & 18.9 \\
\hline Contamination of milk & 11.1 & 16.7 & 7.4 & 25.0 & 14.7 \\
\hline Time consuming & 33.3 & 0.0 & 11.1 & 20.0 & 13.7 \\
\hline Milk loss during processing & 0.0 & 26.7 & 0.0 & 0.0 & 8.4 \\
\hline Lack of firewood for processing & 5.6 & 3.3 & 11.1 & 10.0 & 7.4 \\
\hline Animal hostility & 5.6 & 0.0 & 11.1 & 5.0 & 5.3 \\
\hline Low quality milk during dry season & 0.0 & 3.3 & 3.7 & 10.0 & 4.2 \\
\hline Animal diseases & 11.1 & 0.0 & 0.0 & 5.0 & 3.2 \\
\hline High labour demand & 0.0 & 0.0 & 3.7 & 0.0 & 1.1 \\
\hline $\mathrm{N}$ & 18 & 30 & 27 & 20 & 95 \\
\hline
\end{tabular}

\section{References}

Demissie, B., Komicha, H. H. and Kadir, A. 2014. An analysis of camel and cow milk marketing chain amongst pastoral and agro-pastorals in Gursum and Babile Districts, Ethiopia. Journal of Economics and Sustainable Development, 5(27): 129-138.

Desalenge, Z. 2016. Opportunies and challenges of women in milk value chain development: The case of Batie and Adelie in East Hararegie Zone, Ethiopia. International Journal of Sciences: Basic and Applied Research, 27(3): 2640.

Dupire, M. 1962. Peuls nomades: Etude descriptive des Wodaabe du Sahel Nigerien. Paris: Institut d'Ethnologie.

Gegner, L. E. 2001. Value-added Dairy Options. www.attra.ncat.org (Accessed on $7^{\text {th }}$ January, 2019).

FAO (Food and Agriculture Organization of the United Nations). 1988. Agricultural Development in Nigeria. 1965-
1980. FAO, Rome, Italy.

FAO (Food and Agriculture Organization of the United Nations). 2011. The State of Food and Agriculture (SOFA) 20102011-Women in agriculture: Closing the gender gap for $\mathrm{d}$ e $\mathrm{v}$ e 1 o $\mathrm{p}$ m e $\mathrm{n}$ t. http://www.fao.org/docrep/013/i2 050e/i2050e00.htm (Accessed on 25th April, 2017).

FAO (Food and Agriculture Organization of the United Nations). 2016. Review of the Livestock/Meat and Milk Value Chains and Policy influencing them in Nigeria. Pp 36

Gryseels, G. 1988. Role of livestock on mixed smallholder farms in the Ethiopian highlands. A case study from the Baso and Worena Wereda near Debre Berhan. Dissertation. Agricultural University, Wageningen. The Netherlands. http://www.fao.org/Wairdocs/ILR $\mathrm{I} / \mathrm{x} 5544 \mathrm{E} / \mathrm{x}$ 5544E00.htm\#Contents

Iro, I. 2018. Nomadic Education and 


\section{Cattle milk processing and marketing characteristics}

Education for Nomadic Fulani $\mathrm{r}$ e $\mathrm{t} \mathrm{r}$ e $\mathrm{v}$ e d f $\mathrm{r}$ o m http://www.gamji.com/fulani7.ht m on $26 / 06 / 2018$

Ismail, I. 2010. From Nomadism to Sedentarism: An Analysis of Development Constraints and Public Policy Issues in the Socioeconomic Transformation of the Pastoral Fulani of Nigeria.

Muriuki, H. G. 2001. Smallholder dairy production and marketing in Kenya. In: Rangnekar and Thorpe (Editors) Small holder dairy production and marketing: opportunities and constraints. Proceedings of a South-South workshop held at National Dairy Development Board (NDDB), Anand, India, 13-16.

NLPD (National Livestock Project Division). 1992. National Dairy Survey. NLPD, Kaduna, Nigeria.

Olaluko, E. 1976. Milk Production in West Africa: Objective and Research Approaches, Journal of the Association for the Advancement of Agriculture in Africa, 3: 5-13

Osotimehin, K. O., Tijani, A. A. and Olukomogbon, E. O. 2006 An economic analysis of small-scale dairy milk processing in Kogi State, Nigeria. Livestock Research for Rural Development, 18(11):

Sani, I. 2006. Economic analysis of milk production, processing and marketingin Kaduna State: A case study of the Milk Cooperative Producers' Association Limited (MILCOPAL). Unpublished MSc Thesis. Department of Agricultural Economics and Rural Sociology, Faculty of Agriculture, Ahmadu Bello University, Zaria. 78pp.

Schmidt, K. A., Herald, T. J. and Khatib, K. A. 2009. Modified Wheat starches used as stabilizers in sysetdyle Yoghurt. Journal of Food Quality, 6(2): 29-34.

S o m d a , J ., K a m u a n g a, M ., Münstermann, S., Keita, K. and Mendes, A. 2004. Characteristics of the smallholder dairying farmers in West African countries: Economic viability and paths for improvement. Socio- economic research Working Paper No 2. ITC (International Trypanotolerance Centre), Banjul, The Gambia, 55 pp.

Thornton, D. 2001. Gender benders http://www.google.co.uk/url?q=ht tp://www.mermaidsuk. org.uk /Media/

Waters-Bayer, A. 1986. "Dairy Subsector of the Agropastoral Household Economy." In Livestock Systems Research in Nigeria's Subhumid Zone: Proceedings of a second I.L.C.A./N.A.P.R.I. symposium held in Kaduna, Nigeria, October 29-November 4, 1984, edited by R. von Kaufmann, S. Chater, and R. Blench, 414-426. Addis Ababa: I.L.C.A.

World Bank 1993 Feasibility study on the viability of the Kaduna Federation of Milk Producers' Co-operative Association Ltd.

Yahuza, M. L. 2001. Smallholder dairy production and marketing constraints in Nigeria. In: Rangneker, D. and w. Thorpe Ed. Smallholder dairy production and marketing - Opportunities and Constraints. Proceedings of a South-South workshop held at National Dairy Development board (NDDB), Anand, India, 1316 March 2001 and ILRI (International Livestock Research Institute) Nairobi, Kenya. 44pp.

Received: $22^{\text {nd }}$ August, 2018 Accepted: $21^{\text {st }}$ January, 2019 